\title{
1. Introduction: three reflecting perspectives on interactive governance
}

\section{Jurian Edelenbos and Ingmar van Meerkerk}

\section{EMERGING INTERACTIVE GOVERNANCE IN AN ERA OF BIG SOCIETY}

Interactive governance refers to a situation of reflexive modernity where the expansion of participation and self-organization has become a prerequisite for welfare states. With interactive governance governments can obtain wholeness, coherence and effectiveness, taking into account that governments no longer have the opportunity to directly command and exercise control over their citizens (Bang, 2004).

In recent strands of governance theory there is special focus on interactive governance (Kooiman, 2003; Edelenbos, 2005; Torfing et al., 2012) focusing on the interactions and initiatives of a plurality of public, societal and private actors in dealing with complex societal issues (for example: safety, liveability of city districts, urban development, public service delivery and so on). Although different constellations of public, private and societal actors can be the locus of interactive governance, in this book we specifically aim at interactive forms of governance between governments and citizens. In this respect, interactive governance deals with civic engagement, stakeholder participation, self-organization and civic initiatives. Some, like Putnam (2000), argue that civic engagement is declining; others, like Dalton (2008) and Bang (2009), claim that civic engagement is still present but becomes manifest in different forms.

For an important part, citizens no longer identify themselves with political and governmental establishment belonging to models of representative democracy. Some of them take the initiative to (seek to) engage in public or political affairs outside traditional political institutions, in ways more directly connected to their personal life sphere (Bang, 2009; 
Stolle and Hooghe, 2005). In this perspective some stress that within the present focus on 'smaller government' and 'bigger society' (Kisby, 2010), more and more attention is raised about civil society's self-reliance, self-help and self-organizing power. Apart from these - sometimes political opportunistic ambitions, we can witness a fundamental change in civic engagement regarding public affairs, leading to new forms of community self-organization (Stolle and Hooghe, 2005; Bang, 2009; Marien et al., 2010; van Meerkerk et al., 2013).

\section{GOVERNMENT VERSUS CIVIC INDUCED INTERACTIVE GOVERNANCE}

Interactive forms of governance between citizens and government can be provoked by both citizens and government. In this book we make an explicit distinction between these two forms as they have their own dynamics, often reflect different objectives and give rise to different kinds of implications and challenges. Although we directly admit that the development of interactive governance is often subjected to push-pull processes between citizens and government, this distinction serves, we argue, more than just analytic purposes. These two forms give different meaning to the concept and practice of interactive governance. Government induced interactive governance generally refers to "citizen participation' and has become a significant policy strategy in many Western countries. It has been put, for example, at the heart of spatial planning, social care, regeneration, housing and education policies (for example Irvin and Stansbury, 2004; Marinetto, 2003; Roberts, 2004). It is a form of interactive governance which is strongly organized by governments. This means that governments often decide when, which and how people get involved. At certain moments in decision-making, governments initiate participation procedures in which citizens get a chance to respond to or provide input for decision-making highly structured by rules set by the government. Outcomes from participation procedures are highly uncertain as the government can decide to a large extent how to deal with these outcomes. This often creates dissatisfaction among participants (Edelenbos, 2005) and leads to reluctance about future engagement in 'traditional institutions' or 'participation procedures' of representative democracy (Sørensen and Torfing, 2007).

On the other hand, interactive forms of governance can be provoked bottom-up: by citizens themselves. We choose the term 'civic initiatives' in order to differ from citizen initiatives, which generally refer to democratic processes by which citizens can force a public vote, set the 
political agenda, propose/make new laws or enact statues (Boonstra, 2015; Jameson and Hosack, 1995). Civic initiatives can be initiated by residents, social entrepreneurs, artists and so on, as long as the initiative pursues a community purpose and not a direct business purpose. Several authors argue that this specific form of interactive governance is on the rise in many liberal democracies (for example Bang, 2009; Dalton, 2008; De Moor, 2013; Marien et al., 2010). Civic initiatives reflect new forms of civic engagement, which can be labelled as self-organization (Boonstra and Boelens, 2011; van Meerkerk et al., 2013). Although the phenomenon of bottom-up civic initiatives or citizen self-organization is not new, historical research shows that the current rise can be considered as a new 'wave'. For example, De Moor (2013) in the case of the Netherlands, and Healey (2015) in the case of England, refer to a previous wave at the end of the nineteenth century in which civil society initiatives emerged to address all kinds of needs arising from a rapidly expanding urban working class population.

These bottom-up civic initiatives can arise from dissatisfaction with or complaints about governmental policy and actions, functioning as a response to them. To avoid being marginalized as exclusively negative and driven by NIMBYism (Not In My Back-Yard), citizens develop alternatives to government proposals. We also see civic initiatives emerging in spaces that governments withdraw from due to budget cuts, and in domains that 'slipped' governmental attention. Today, and this differs from traditional forms of citizen engagement, citizens want to engage in informal and loosely structured organizations (Lorentzen and Hustinx, 2007; Stolle and Hooghe, 2005; Wyler and Blond, 2010) and keep aloof from existing political and governmental structures and procedures, which they consider no longer legitimate and/or effective. We see self-organization being shaped in new and different structures, like community trusts and community foundations. These civic initiatives take different forms and are emerging in different fields. They range from running a community facility, such as a community centre, setting up a cooperative or charity to provide community-led care services for older people in the area, to environmental initiatives aiming to provide local renewable energy. In these self-organizations, societal actors take the initiative and aim to develop ideas and projects on their own, without (much) interference from governmental and political institutions. In this way, bottom-up initiatives of empowered and highly educated citizens emerge today that are no longer fully initiated, conditioned and controlled by government (Marien et al., 2010; van Meerkerk et al., 2013). In 
this way self-organization has the potential for association, selfdevelopment, learning and local ownership, as is emphasized by developmental models of democracy (MacPherson, 1979), inspired by the work of John Stuart Mill and De Tocqueville.

\section{INTERACTIVE GOVERNANCE AS THE RESPONSE TO MANY CHALLENGES?}

Interactive governance can be approached as a response to the increasing societal complexity, dynamics and diversification that undermine the ability to govern society in an effective, efficient and legitimate way through the traditional means of hierarchy and market (Sørensen and Torfing, 2007). It can also be seen as a specific dimension of governance networks as it specifically focuses on the way societal and private actors are engaged in complex decision-making processes and networks and how this engagement relates to (inter)governmental processes (Edelenbos, 2005). The concept of interactive governance has special interest in and focuses on the way participation and self-organization of stakeholders take place in decision-making processes dealing with complex public issues (van Meerkerk, 2014).

There are high hopes with interactive governance as in the literature it is often assumed that the involvement of societal stakeholders can develop and enhance the efficiency, effectiveness and legitimacy of decision-making, implementation and service delivery (Edelenbos and van Meerkerk, 2016). First, interactive governance may increase effectiveness and efficiency. In complex decision-making processes stakeholders have different and conflicting perceptions on the problem and solution definitions (Torfing et al., 2012). Stakeholders' interests can collide, leading to process stagnation as stakeholders might block decision-making. Through the involvement of stakeholders it is argued that the use of veto power by unsatisfied actors will decrease and therefore support for decisions will increase. Processes are accelerated, leading to increasing efficiency (Kooiman, 1993). Furthermore, it is often claimed that interactive governance leads to improved effectiveness of decision-making in complex networks (Pierre and Peters, 2000). Due to fragmentation in society resulting from individualization, labour functionalization and specialization, interactive governance can contribute to coordination and integration (Rhodes, 1997; Edelenbos and Teisman, 2011). Interactive governance becomes a means to realign dispersed resources, such as financial means, human resources, information, knowledge, competences and support. Interactive governance has the potential 
to combine or compromise the different resources so that effective and efficient results are reached. It is argued that the alignment of resources enhances the collective capacity to durably solve wicked societal problems (Koppenjan and Klijn, 2004).

Second, interactive governance creates new democratic spaces in which new political identities of citizens can be developed (Beck et al., 1994; Warren, 2009). On the one hand, people no longer strongly identify with the existing political system (the regime, its institutions, norms and principles) based on representative democracy. 'Citizens no longer primarily get their political identity from their identification with political parties' (Bang, 2009: 126). On the other hand, governments are also 'reinventing' themselves in order to adapt to a changing societal context, trying to overcome lost meaning and identity in contemporary selfreflexive modern society (Beck et al., 1994). This also stimulates interactive forms of governance in which active citizens are mobilized and new (participation) channels are created to restore political meaning and identity (March and Olsen, 1995).

Next to giving shape to new political identities, interactive forms of governance are often legitimized to restore trust in existing governmental and political institutions. The legitimacy of liberal and representative democracy is under pressure in many Western countries. Through interactive governance people find new ways to bridge the gap between government and politics on the one hand and stakeholders and citizens on the other, because the latter have more room for engagement through participation and self-organization (Hajer and Wagenaar, 2003; Lowndes et al., 2001; Stolle and Hooghe, 2005; Dalton, 2008). Interactive governance may supplement institutions of representative democracy, giving more opportunity for direct citizen involvement, deliberation and transparency. This may increase the throughput legitimacy of governance processes as valuable input from stakeholders is considered, assessed and processed in decision-making (van Meerkerk et al., 2015).

However, the rise of interactive governance and civic initiatives is not without problems, issues and discussion. For example, responsibility and accountability issues are raised (Hajer and Wagenaar, 2003; Klijn and Skelcher, 2007) and problems of exclusion and representation are discussed (Mayer et al., 2005; Uitermark, 2014; Bang, 2009). We also lack knowledge and discussion of the output and outcome of interactive governance, about its effectiveness and efficiency, but also its legitimacy. We need a more encompassing critical reflecting view to fully discuss the potentials and problems of interactive governance. This critical reflecting view can be developed by the use of three perspectives: the instrumental, 
the cultural and the democratic perspective. We develop these three perspectives on interactive governance in the next section.

\section{CRITICALLY REFLECTING INTERACTIVE GOVERNANCE VIA THREE PERSPECTIVES}

\subsection{Introducing the Three Perspectives on Interactive Governance}

The objective of this book is to critically reflect on the concept of interactive governance and whether its assumed added value is reached, and to reflect on related issues of interactive governance and new trends and developments that go along with it. Therefore the main title of the book is Critical Reflections on Interactive Governance. These critical reflections take different forms in the various book chapters. They can be grounded in thoughtful reasoning based on personal argumentation, theory and empirical cases and illustrations. We have explicitly invited contributions that use theory, theoretical argumentation and empirical illustrations to critically discuss and reflect on the phenomenon of interactive governance. To provide some order for the coming reflections, we position and elaborate government-induced and citizen-induced interactive governance according to three different perspectives: the instrumental, cultural and democratic perspective (see Table 1.1). Below we outline the main aspects and complementarities between the three perspectives on interactive governance (cf. Sørensen and Torfing, 2007). We directly admit that in order to produce such order there is always some degree of oversimplification. However, we believe these three perspectives are distinctive enough, while also capturing the main works / body of literature on interactive governance (both government and civic induced).

The instrumental perspective is strongly connected to the public administration literature on interactive governance. It approaches interactive governance as a medium for interest mediation between interdependent actors, who have their own resources (for example Kooiman, 2003; Koppenjan and Klijn, 2004; Rhodes, 1997). Interactive governance is then the result of the strategic actions of autonomous actors who interact because of their mutual resource dependencies. Actors are in essence approached as rational (whether limited or not) and calculative, meaning that actors make decisions based on their preferences and on anticipations of the future effects of current actions (March, 1994). In this perspective interactive forms of governance help in enhancing effectiveness and efficiency in solving specific public (wicked) issues and in governing society more generally. 
Table 1.1 Overview of the three perspectives on interactive governance

\begin{tabular}{|c|c|c|c|}
\hline & $\begin{array}{l}\text { Instrumental } \\
\text { perspective }\end{array}$ & $\begin{array}{l}\text { Cultural } \\
\text { Perspective }\end{array}$ & $\begin{array}{l}\text { Democratic } \\
\text { perspective }\end{array}$ \\
\hline $\begin{array}{l}\text { Origin/theoretical } \\
\text { ground }\end{array}$ & $\begin{array}{l}\text { Public } \\
\text { administration/ } \\
\text { management with } \\
\text { focus on efficient } \\
\text { and effective } \\
\text { governance } \\
\text { processes }\end{array}$ & $\begin{array}{l}\text { Sociology/social } \\
\text { psychology with } \\
\text { focus on group } \\
\text { dynamics and } \\
\text { relationships }\end{array}$ & $\begin{array}{l}\text { Political science } \\
\text { with focus on } \\
\text { democratic control, } \\
\text { responsibility and } \\
\text { accountability in } \\
\text { decision-making }\end{array}$ \\
\hline Main focus & $\begin{array}{l}\text { Actors in the } \\
\text { network and their } \\
\text { strategic } \\
\text { interactions }\end{array}$ & $\begin{array}{l}\text { Group of actors and } \\
\text { role-seeking } \\
\text { behaviour of actors }\end{array}$ & $\begin{array}{l}\text { Institutional } \\
\text { context of actors in } \\
\text { politics and polity }\end{array}$ \\
\hline Assumption/drive & $\begin{array}{l}\text { Actors have their } \\
\text { own interests } \\
\text { which drive their } \\
\text { behaviour }\end{array}$ & $\begin{array}{l}\text { Actors want to } \\
\text { belong to groups } \\
\text { (identities) and are } \\
\text { socialized by these } \\
\text { groups }\end{array}$ & $\begin{array}{l}\text { Actors seek public } \\
\text { support and public } \\
\text { value for their own } \\
\text { (planned) actions }\end{array}$ \\
\hline $\begin{array}{l}\text { Objective } \\
\text { interactive } \\
\text { governance }\end{array}$ & $\begin{array}{l}\text { Interactive } \\
\text { governance as } \\
\text { strive for } \\
\text { effectiveness and } \\
\text { efficiency }\end{array}$ & $\begin{array}{l}\text { Interactive } \\
\text { governance as } \\
\text { strive for identity } \\
\text { development and } \\
\text { enactment }\end{array}$ & $\begin{array}{l}\text { Interactive } \\
\text { governance as } \\
\text { strive for } \\
\text { legitimacy }\end{array}$ \\
\hline
\end{tabular}

The cultural perspective has its origin in sociology and social psychology. It approaches interactive governance as a medium for enacting and developing identity. On the one hand, citizens are searching for new forms of civic engagement, and interactive governance provides a medium for enacting new political identities (Bang, 2009; March and Olsen, 1995; Marinetto, 2003; Taylor, 2007). On the other hand, governments are seeking new roles in contemporary self-reflexive modern society (Beck et al., 1994). Actors in this perspective are situated in their social context and approached as role seeking and rule following (March, 1994; March and Olsen, 1995). They want to belong to certain groups and their identities are socialized by these groups. Identities in this respect are both constructed by individuals and imposed upon them (Giddens, 1984).

The democratic perspective is basically grounded within political science (but this perspective is also strongly elaborated within the public administration literature). It approaches interactive governance as a phenomenon delivering normative questions (problems and potentials) in 
terms of democratic control, public accountability and responsibility (for example Van Kersbergen and Van Waarden, 2004; Papadopoulos, 2003; Sørensen, 2002). It is not so much the interests or identities of actors that are of central attention, but how interactive governance is related to the institutional context of politics and polity. Actors in this perspective are approached as seeking or lacking legitimacy in a multiple institutional context (representative and deliberative democracy situations) for their actions and political agenda.

As noted above, we make a further distinction between governmentinduced interactive governance (participation) and civic-induced interactive governance (self-organization). Combined with the above stated three perspectives, in total three different overview tables appear. In this book the critical perspective on interactive governance is the main focus and therefore the three tables contain a positive and critical stance in order to theoretically reflect on how interactive governance is and can be framed, depending on the theoretical point of departure one takes.

\subsection{The Instrumental Perspective on Interactive Governance}

Table 1.2 provides an overview of the instrumental perspective on government-induced and citizen-induced interactive governance from a positive and critical stance. Government-induced interactive governance is often justified as improving the effectiveness of public governance. Wicked issues demand that different kind of actors next to governmental actors have to be involved. By involving the resources and knowledge of citizens, government-induced interactive governance can enhance effective and integrative policy-making (Koppenjan and Klijn, 2004; Sørensen and Torfing, 2007). In response to wicked policy issues that cross different sector and organizational boundaries, interactive governance can lead to more integrated responses, partly overcoming the issue of fragmentation (Edelenbos and Teisman, 2011; Rhodes, 1997). Next to the potentials of greater policy coordination, access to community capacity and local knowledge, the impetus for government-induced interactive governance often comes from a need to obtain acceptance as a prerequisite for successful implementation (Irvin and Stansbury, 2004). Achieving interesting outcomes often depends on finding attractive solutions, which encourage actors to activate their resources and knowledge for the problem and/or policy process at stake. When actors acknowledge their interdependent relationships to other actors in the governance network, they are more inclined to join forces and to combine and bundle their resources (financial assets, knowledge, and so on), leading to increased effectiveness and synergies. 
From a critical stance stakeholder participation can be costly and time-consuming. By including many different relevant and affected actors, decision-making processes can be lengthy and need a great deal of capacity and investments. Interactive governance processes are not selfexecutive and need extensive process or network management activities (Edelenbos and Klijn, 2006; Sørensen and Torfing, 2009). Furthermore, by including many different relevant and affected actors in the process, a number of interests affect the result, increasing the chance of raising costs of possible results which are politically difficult to ignore (Irvin and Stansbury, 2004). At the same time interactive governance processes may also form a threat for effectiveness as these processes imply involvement of many stakeholders with diverse and often conflicting sets of values and interests. These processes may lead to intense debates, quarrels and firm conflicts which are often hard to handle, leading to process stagnations and even deadlocks and impasses (Koppenjan and Klijn, 2004).

The impetus for civic-induced interactive governance is that citizens get or take the opportunity to develop their own solutions for persisting problems. Interactive governance is then an instrumental tool for citizen groups to collect resources and develop problem-solving capacity and to realize their own community projects (for example van Meerkerk et al., 2013). This bottom-up approach provides the opportunity to develop more tailor made solutions, taking specific situations and local problems and citizen preferences into account. The civic-induced form of interactive governance creates commitment and ownership, which is essential to the creation of local vitality and capacity (Stolle and Hooghe, 2005; Bang, 2009).

From a critical stance, civic-induced interactive governance is also time consuming and takes a lot of effort; citizens with time on their hands have the opportunity to become active and self-organizing citizens. Next, there is always the risk of free-riding behaviour of other community members (Ostrom, 1998). Furthermore, deliberated civic initiatives can be endangered by cherry-picking behaviour on the part of decision-makers or reluctance to provide the necessary resources for realizing these proposals (Edelenbos, 2005). Such proposals produced by civic initiatives could easily change or even evaporate when they have to pass formal policy and decision-making structures and arenas. Lastly, civic-induced interactive governance often requires some kind of political, financial or technical support from governmental institutions, or, more likely, some combination of these three, in order to gain the necessary impact. In this respect, citizen collectives often face a central dilemma between, on the one hand, modifying and adapting their behaviour to work with the state, thereby increasing their opportunities to receive support (for example funding), and on the other hand the freedom 
of functioning and working at a distance from the state without such support (Munro, 2008).

\section{Table 1.2 Instrumental perspective on interactive governance from a positive and critical stance}

\begin{tabular}{|c|c|c|}
\hline Instrumental perspective & $\begin{array}{l}\text { Government-induced } \\
\text { interactive governance }\end{array}$ & $\begin{array}{l}\text { Community-induced } \\
\text { interactive governance }\end{array}$ \\
\hline $\begin{array}{l}\text { Positive stance } \\
\text { (e.g. Edelenbos, 2005; } \\
\text { Irvin and Stansbury, 2004; } \\
\text { Kooiman, 2003; Leach } \\
\text { and Pelkey, 2001; Van } \\
\text { Meerkerk et al., 2013) }\end{array}$ & $\begin{array}{l}\text { Citizen participation } \\
\text { needed for gaining support, } \\
\text { tapping knowledge and } \\
\text { community energy, } \\
\text { improving the } \\
\text { effectiveness and } \\
\text { efficiency of governmental } \\
\text { policy and } \\
\text { decision-making }\end{array}$ & $\begin{array}{l}\text { Governments need the } \\
\text { self-organizing power to } \\
\text { ensure the welfare state and } \\
\text { citizens approach } \\
\text { interactive governance as a } \\
\text { tool by which they can } \\
\text { realize their own preferred } \\
\text { projects }\end{array}$ \\
\hline $\begin{array}{l}\text { Critical stance } \\
\text { (e.g. Edelenbos, 2005; } \\
\text { Irvin and Stansbury, 2004; } \\
\text { Kooiman, 2003; Mayer et } \\
\text { al., 2005) }\end{array}$ & $\begin{array}{l}\text { The interactive process is } \\
\text { time- and resource- } \\
\text { consuming, leading to } \\
\text { inefficient and ineffective } \\
\text { outcomes as too many } \\
\text { actors, interests and values } \\
\text { have to be reckoned with, } \\
\text { enhancing the chance of } \\
\text { conflict and deadlocks }\end{array}$ & $\begin{array}{l}\text { There is always some kind } \\
\text { of government } \\
\text { participation providing } \\
\text { resources to make } \\
\text { interactive governance } \\
\text { happen, and it is to be seen } \\
\text { whether government takes } \\
\text { over or supports the citizen } \\
\text { projects }\end{array}$ \\
\hline
\end{tabular}

\subsection{The Cultural Perspective on Interactive Governance}

Government-induced interactive governance from a cultural perspective is framed as overcoming lost meaning and identity in contemporary society (Beck et al., 1994; Bang, 2004). In order to deal with the amount of internal and external complexity, governors and governments are no longer able to steer directly from a uniform steering centre and are reinventing new steering roles. Policy-makers and politicians try to overcome this 'lost identity' by developing new information and participation channels from state to society in which they take a different role. Politicians, for example, who are trying to become meta-governors in order to adapt their roles in interactive governance try to shape and steer processes of interactive governance (Sørensen and Torfing, 2007). Public managers are increasingly taking a facilitative and boundary-spanning role to deal with the complexity of reflexive modernity (van Meerkerk, 2014; Williams, 2002). 
Seen from a critical stance, government is inventing new, indirect modes of steering, but these represent a new kind of top-down steering: one that is empowering but self-disciplining (Dean, 2003; Foucault, 1991). In the words of Bang (2004: 158): 'A new top down leadership and management for empowering and partnering across old boundaries between public, private and voluntary sectors is forming new "governmentalities" for ruling society indirectly by designing, facilitating and moderating processes of self- and co-governance'. The participation channels are strongly defined and structured by governments, determining who can participate, at what time and under which conditions. The focus (content), way (process) and context are strongly determined, leaving almost no freedom and room for delivering the input people would like to give. So in the end the channels do not work in providing new political identity as it is still strongly steered by the state (Marinetto, 2003; Taylor, 2007). Identity development is still considered a one-way stream. Citizen participation is therefore received as a symbolic act, a marginal process, and a manipulative process or pathological ritual.

Civic-induced interactive governance is framed as creating new democratic spaces in which new political identities of citizens can be developed (Beck et al., 1994; March and Olsen, 1995; Warren, 2009). People no longer strongly identify with the existing political system (the regime, its institutions, norms and principles) based on representative democracy. For example, there seems to be consensus among political scientists that there has been a decline in citizens' participation in the traditional forms of political engagement that have been part and parcel of the representative democratic system in the last decades. This decline is mostly demonstrated by citizens' decreasing membership of political parties and by decreasing electoral participation; but other institutionalized forms of political engagement, such as participation in or membership of biginterest organizations, are also declining (Dalton, 2004; Marien et al., 2010; Peters, 2010). Citizens no longer primarily get their political identity from their identification with political parties (Bang, 2009) and are exploring new forms of engagement. Interactive governance therefore provides a medium for developing and enacting new political identities. In these new forms of civic engagement, citizens organize themselves through informal and loosely structured organizations (Bang, 2009; Hurenkamp et al., 2006; Stolle and Hooghe, 2005). Initiators of these self-organizing initiatives are driven by personal experiences or an interest in taking care of their own neighbourhood or community, often in reaction to a (new) governmental intervention or a societal event.

From a critical stance, civic-induced interactive governance gives shape to new divides among those citizens who are capable of organizing 
themselves on the basis of reciprocity. A growth of citizen selforganization implies that people become more dependent on the strength of their social network (its bridging and bonding capital). Self-organizing capacity is likely to be unequally dispersed among citizens, leading to issues of inequality (for example Uitermark, 2014). Furthermore, power can be concentrated in the hands of a few well organized citizens. And just because self-organizing citizen groups are connected around a particular kind of identity, they can be exclusive. Next to some kind of exclusive identity, in order to function effectively, homogeneity and exclusion are often helpful, if not necessary, in the context of selforganization (Dietz et al., 2003). Interactive governance becomes a vehicle for those stakeholders with much more resources (information, money, time, skills and so on) to exert influence on policy-making and service provision that serves their private interests under the label of community and joint interests (Taylor, 2007).

\section{Table 1.3 Cultural perspective on interactive governance from a positive and critical stance}

\begin{tabular}{l} 
Cultural perspective \\
\hline Positive stance \\
(e.g. Bang and Sørensen, \\
1999; Beck et al., 1994; \\
March and Olsen, 1995; \\
Torfing et al., 2012)
\end{tabular}

Critical stance

(e.g. Bang, 2004; Dean, 2003; Foucault, 1991; Sørensen and Torfing, 2007; Taylor, 2007; Rose, 1999; Uitermark, 2014)

$\begin{array}{ll}\begin{array}{l}\text { Government-induced } \\ \text { interactive governance }\end{array} & \begin{array}{l}\text { Community-induced } \\ \text { interactive governance }\end{array} \\ \begin{array}{l}\text { Governments trying to } \\ \text { overcome lost meaning and } \\ \text { restore political identity in } \\ \text { contemporary self- }\end{array} & \begin{array}{l}\text { Citizens giving shape to } \\ \text { new social-political } \\ \text { reflexive modern society } \\ \text { by adapting their roles and } \\ \text { generating new }\end{array} \\ \begin{array}{l}\text { governance is a way to give } \\ \text { shformation and }\end{array} & \begin{array}{l}\text { social-political identities } \\ \text { and new forms of civic } \\ \text { engagement }\end{array}\end{array}$

participation channels to society

Government develop new conditions (rules, language, etc.) to give shape to active citizenship which doesn't provide much room and freedom for citizens, with the result that citizens resist this 'selling" of new government identities
Development of citizen self-organization can lead to elite capture due to power and skills inequalities; it implies a new divide between capable and skilled self-sufficient citizens and less educated and skilled depended citizens (leading to a 'meritocracy') 


\subsection{The Democratic Perspective on Interactive Governance}

Governments approach interactive governance as a good opportunity to restore the trust of citizens in government and politics. Trust of citizens in political and governmental institutions has been under pressure for a number of decades now (Hardin, 1999; Tolbert and Mossberger, 2006). Politicians are seen as power animals who are focused on personal or political gain and reputation, without taking the interests and values of citizens into account. Governments are viewed as big machineries and bureaucracies which are greatly involved with internal affairs (bureau politics) and procedural rationality without a real eye and feeling for what is happening in society. Therefore interactive governance is seen as a way to reconnect with society (Edelenbos, 2005; Hajer and Wagenaar, 2003; Sørensen and Torfing, 2007). Through organized events and processes of interactive governance, citizens and the wider community become realigned with politics and government and get to know what politics is about and, vice versa, politicians get to know what is felt to be important in society, and what should be included in policies, plans and political ambitions (Bang and Sørensen, 1999; Mayer et al., 2005). Interactive governance in this perspective is about building new bridges between society and government, giving more space for deliberative democracy (Dryzek, 2010) as a means to enhance throughput legitimacy of policy and decision-making (van Meerkerk et al., 2015). Governance networks provide the means to engage a wider range of actors and connect with them in new ways that are more focused on deliberation, constructive dialogue and developing mutual understanding. In this way interactive governance processes can supplement representative democracy (Klijn and Skelcher, 2007; Pierre and Peters, 2000).

In a critical perspective, this realignment with society is questioned because it can lead to populist behaviour (Oesch, 2008). New political parties arise that question 'old politics' and tell and sell that they really listen to citizens in order to maximize their votes and gain political power. Moreover, it can also lead to even further decreasing trust as government and politics can't live up to raised expectations. In reconnecting with society citizens expect that their input (values, interests, worries and so on) are seriously taken into account. When these expectations are not met, citizens will turn away even more from politics and governments (Irvin and Stansbury, 2004; Mayer et al., 2005). Some evaluative studies on participation and self-organization critically analyse the way governments are really interested in the values and interests of stakeholders and that interactive governance often runs parallel to real decision-making processes without real meaning and impact (Edelenbos, 
2005). Governments strongly determine and in practice narrow down the agenda and the possibilities to give input. Authorities often lack experience and abilities with interactive governance, fear losing power, and are unwilling to adapt, leading to interactive governance often remaining limited to providing information or consultation (Leach and Pelkey, 2001). This in the end leads to further decreasing trust of citizens in politics and to an even wider gap between government and society.

Regarding the civic-induced perspective on interactive governance citizens (aim to) take more responsibility and bear more accountability for public service provision. Especially those services (social cultural services: library, health care and so on) that are under pressure during cutbacks, financial hard times and reorganizations may lead to civic initiatives aimed at improving the provision and quality of those public services. Nowadays the focus is on 'smaller government' and creating 'bigger society' (Kisby, 2010), in which more and more attention is raised for civil society's self-reliance, self-help and self-organizing power. In these 'bigger societies', citizens become more actively engaged in various ways in becoming new producers of public values and services (Warren, 2009). In this respect, interactive governance has the potential for association, self-development, learning and local ownership of citizens, which may enhance democratic development and empowerment (Hirst, 2000).

From a critical stance it is argued that these new forms of stakeholder engagement by means of self-organization might conflict with the classical representative institutions. Klijn and Skelcher (2007), for example, discuss a situation in which representative democracy models are incompatible with processes of interactive governance. In the literature, attention has been given to the tensions between the horizontal accountability structure of interactive governance networks and the vertical accountability structure of representative democratic institutions (for example Hirst, 2000; Le Galès, 2001; Pierre, 2000), to the democratic character of (governance) networks, and to discussions on how to improve the democratic quality of networks (Sørensen and Torfing, 2007). We still know little about how citizen self-organizations effectively and legitimately develop in interaction with existing political and governmental institutions (Stolle and Hooghe, 2005). Interactive governance in this critical stance is approached as a threat to political accountability and hollowing out of the state (Klijn and Skelcher, 2007). 
Table 1.4 Democratic perspective on interactive governance from a positive and critical stance

\begin{tabular}{|c|c|c|}
\hline Democratic perspective & $\begin{array}{l}\text { Government-induced } \\
\text { interactive governance }\end{array}$ & $\begin{array}{l}\text { Community-induced } \\
\text { interactive governance }\end{array}$ \\
\hline $\begin{array}{l}\text { Positive stance } \\
\text { (e.g. Hajer and Wagenaar, } \\
\text { 2003; Dryzek, 2010; De } \\
\text { Moor, 2013; Fung and } \\
\text { Wright, 2003; Van } \\
\text { Meerkerk, 2014; Warren, } \\
\text { 2009) }\end{array}$ & $\begin{array}{l}\text { Governments try to bridge } \\
\text { the gap with society and } \\
\text { citizens, and to restore trust } \\
\text { in governmental and } \\
\text { political institutions by } \\
\text { supplementing } \\
\text { representative democracy } \\
\text { with deliberative and } \\
\text { participatory processes }\end{array}$ & $\begin{array}{l}\text { Citizens take more } \\
\text { responsibility and bear } \\
\text { accountability for cutbacks } \\
\text { in service provision, } \\
\text { forgotten ambitions and/or } \\
\text { lack of results from } \\
\text { previous governmental } \\
\text { programmes and projects }\end{array}$ \\
\hline $\begin{array}{l}\text { Critical stance } \\
\text { (e.g. Betz, 1993; Mayer et } \\
\text { al., 2005; Edelenbos, } \\
\text { 2005; Van Meerkerk, } \\
\text { 2014; Klijn and Skelcher, } \\
\text { 2007) }\end{array}$ & $\begin{array}{l}\text { Governments do not } \\
\text { adequately connect to } \\
\text { citizens, which in turn } \\
\text { backfires and leads to even } \\
\text { further decreasing trust and } \\
\text { broader cleavage leading in } \\
\text { the end to a further } \\
\text { downgrading spiral in the } \\
\text { relationship between } \\
\text { government and society }\end{array}$ & $\begin{array}{l}\text { Citizens take too much } \\
\text { responsibility which they } \\
\text { can't bear, leading to } \\
\text { problems of public } \\
\text { accountability and } \\
\text { liability; interactive } \\
\text { governance becomes a } \\
\text { vehicle to gain public } \\
\text { resources for self- } \\
\text { interested individuals or } \\
\text { community groups }\end{array}$ \\
\hline
\end{tabular}

\section{STRUCTURE OF THE BOOK: INTRODUCING THE CHAPTERS}

The contributions specially pay attention to important issues of interactive governance, taking into account the two-way distinction of government initiated participation processes and projects on the one hand and civic initiated self-organization processes on the other hand, as discussed in the previous sections. All contributions take a critical stance towards interactive governance, reflecting on the emergence, meaning and form of interactive governance or discussing critical aspects for making interactive governance work in politics and public governance.

The book starts with two more general contributions by Kooiman (Chapter 2) and Peters and Pierre (Chapter 3). Kooiman in his chapter presents the foundations of his approach to interactive governance and governability, and the way it has been used and developed in empirical research. In this chapter interactive governance is defined as the whole range of interactions to solve societal problems and to create societal 
opportunities, the formulation and application of principles guiding those interactions and the care for institutions enabling them. Governability is seen as the overall quality for governance of any societal entity, divided into a system-to-be-governed, a governing system and a system of interactions mediating between the two. Diversity, complexity, dynamics and scale are argued to be major variables influencing the governance and governability of societal entities. In such governance the state, market and civil society play roles; Kooiman argues that these should be analysed at both an actor and a structural level.

In their contribution (Chapter 3) Peters and Pierre address the linkage between types of policy problems and the processes used to address them. They focus on the challenging question: what processes are likely to be most effective in addressing wicked problems? That question, however, makes several important assumptions, which they deal with in their contribution. The first is that there is a single type of wicked problem, and therefore a single process that can be most effective in addressing, if not solving, those problems.

\subsection{Reflections on Democracy: Issues and Principles}

As argued in the second section of this chapter, interactive governance, whether in the form of government-led participation or civic induced, provides chances and challenges for the democratic quality of the governance of public issues. Moreover, to understand the democratic consequences of interactive governance, it is also important to take into account the context and discourse in which interactive governance emerges. In several chapters the democratic issues and challenges related to interactive governance and its institutional context are discussed. In these chapters several democracy principles and issues such as representativeness, authority, accountability, inclusiveness and transparency are raised. However, positive aspects also come to the fore, such as interactive governance enhancing deliberation, empowerment, capacity building, learning and communication. Some even claim that citizen self-organization complements existing democracy models with its pragmatic focus on real-life action and implementation, and that this form, in contrast to traditional citizen participation, engages a more diverse group of citizens. What is the institutional and cultural context that should be taken into account and what is the balance between positive and negative issues in interactive governance? Several contributors critically reflect on this theme of interactive governance.

In his contribution (Chapter 4) Bang argues that governance analysis has exploded in recent years, and it has become nearly impossible to tell 
how the concept and practice of governance differs from the concepts and practice of government and state. In addition, governance analysis has been placed more and more in the shadow of the new institutionalisms and, most of all, of neoliberalism as the new way of the world. Bang constructs the argument that it has become part of the 'institutional bricolage' undertaken by strong strategic actors to acquire control over each other and to 'nudge' laypeople to make the right choices in order to make them functional for boosting competition and growth. However as Bang continues his argument - interactive governance is not a property or effect of institutions, nor does it apply solely to those individuals who seek success above everything else. How then to bring laypeople back in? Bang reflects on the institutional developments behind this question and explores avenues in providing an answer.

The starting point of Chapter 5 by Wagenaar consists of a paradox and an observation. The paradox is that the countless current initiatives with public participation or interactive governance do not necessarily result in an expansion or deepening of institutionalized liberal democracy. The related observation is that we cannot understand the full import of public participation in contemporary liberal-electoral democracy without taking its political economy into account. Wagenaar argues that an explanation for this observation and paradox can be found in the double hegemony of democratic elitism and everyday neoliberalism. What is this double hegemony and what can be done to overcome democratic impairment in the face of this double hegemony? Wagenaar elaborates these questions in his chapter. With regard to the latter, he proposes a strategy of 'democratic transfer', the transfer of democratic forms and practices that originate and flourish in the civic sphere to political society. This strategy consists of two steps: 'redescription' and 'redesign' of the relation between political elites and the public.

With an increase in self-governance arrangements and civic initiatives, a new channel for citizen participation has developed in addition to traditional representative democracy. In Chapter 6, Røiseland and Vabo argue that large parts of the theoretical literature tend to see selfgovernance and civic initiatives as a fruitful and welcomed expansion of democracy, presuming classic representative democracy and newer forms of civic initiatives can go hand in hand. However, from the perspective of political leadership theory, it is not obvious that representation and direct participation can be linked together in any easy way. Some would even argue that there is a deep and insoluble tension between the two models of participation. This chapter elaborates on this possible tension by developing a typology of possible outcomes of different kinds of interactive governance, providing empirical examples from urban governance 
research. Røiseland and Vabo also discuss how the possible gap between representation and direct participation can be diminished.

In Chapter 7 Papadopoulos discusses the argument around whether the growth of interactive forms of governance can be seen as an improvement of the quality of democracy through the advent of less hierarchical forms of regulation, in which negotiation and deliberation with policy takers are the norm. Papadopoulos holds the view that such an assessment should be subjected to critical scrutiny. He therefore discusses in his contribution the following three crucial facets of interactive governance's democratic credentials: ex ante authorization (explicit delegation or not, and if so by whom); representation (of which constituencies and interests) and effective stakeholder participation (decisional influence); ex post accountability (for what, to whom, how, and with what kinds of consequences).

Søndergård Madsen and Triantafillou (Chapter 8) stress the importance of how power and empowering take shape in interactive governance, thereby taking a cultural perspective. In Nepal, one of the poorest countries in the world, a number of empowerment programmes and self-help community groups have sprung up during the past decade. Søndergård Madsen and Triantafillou examine how and with what political effects empowerment was linked to poverty alleviation in Nepal through the Local Governance and Community Development Programme (LGCDP). They argue that the alleviation of poverty was not an immediate, but rather a long-term, objective of the programme. Building on Foucault's analytics of power and freedom, they critically reflect on the political implications of empowerment-based poverty alleviation for the strategies that the poor can legitimately adopt in order to improve their economic situation. The authors argue that such self-improvement should take place through peaceful, democratic deliberation as the preferable form of participation.

In Chapter 9 Moyson, van de Walle and Groeneveld take a critical look at the views public officials have of citizens, in particular their level of trust toward citizens' ability, integrity and benevolence, when engaging in administrative interactions. Public officials' trust is essential in interactive governance, because it may stimulate the compliance and trust of citizens toward public administration. In turn, this may increase the effectiveness of public service delivery. Public officials' trust builds over time when they have interactions with trustworthy citizens. Hence, trust between public officials and citizens is at the same time an essential requirement for interactive governance and an outcome of such interactions. Extensive research thus far has not yet revealed many individual factors of officials' trust toward citizens or their perceptions of citizens' trustworthiness. In 
addition, few studies have been conducted on the institutional and organizational factors of trust and trustworthiness. Moyson et al. discuss this research and subsequently suggest avenues for future studies.

The focus of Sobels in Chapter 10 is on empirical evidence of 'governance in flux' as budget cuts, evolving water policy, its associated legislation for regional Water Allocation Plans in South Australia, and economic imperatives change the relationship of government, commerce and community. According to him, the previous relationship in this context was very much an autocratic, 'top-down' style of government administration, with government policing compliance of water licence holders who extract water from farm bores licensed for irrigation. Sobels argues that this instrumental approach of interactive governance was strongly dominating, at the expense of a more democratic and cultural approach. More recent negotiations by local industry associations on behalf of irrigators moved through a period of up to ten years of 'community engagement', representing a new phase of democratic interactive governance. However, the process has continued to evolve, such that the new rules of how to share the groundwater are indicative of a power shift to irrigators, who are in the process of establishing the new rules as expected norms of behaviour, and values inherent in practices. Sobels concludes that there is an increasing cultural form of interactive governance emerging. He closes his contribution by suggesting a hierarchical and evolutionary order in the different forms of interactive governance.

Denters discusses in Chapter 11 the potentials and pitfalls of community self-organization. He introduces the distinction between invited and created spaces. This distinction resembles the difference between government-induced and civic-induced interactive governance as discussed at the beginning of this introductory chapter. In his chapter, Denters elaborates the ACTIE framework which can be used to analyse important features and factors of civic initiatives such as aims and ambitions, talents and time and institutionalization of civic-induced interactive governance. Denters argues that these factors determine to a large extent the effectiveness and legitimacy of community selforganization.

\subsection{Reflections on Constructing Co-producing Relationships}

Interactive governance doesn't take place in an institutional vacuum. All kinds of procedures, ways of working and roles do exist, mainly introduced from an existing, liberal-representative democracy tradition. Interactive governance therefore soon meets government rationality. It is 
interesting to discuss how interactive governance is related to government. Government actors can respond in certain ways to participation and self-organization; they can be, for instance, resistant or accommodative. How do government actors (officials, civil servants and politicians) approach and value interactive governance and which position and roles do they take in dealing with processes of interactive governance? Do they need to be regulative, facilitative, directive and so on? Governments may also approach interactive governance as opportunities to meet budget cuts and financial problems. From the new emerging relationships between citizens and government actors, new co-productive forms and partnerships may arise. This co-production may develop regarding the connection of different sources of knowledge (local, bureaucratic, expert) or in general regarding alignment of activities and finding new collective action logic. The following chapters discuss these topics.

In Chapter 12 Bovaird and Loeffler argue that promotion of more intensive user and community co-production not only opens up new potential for a transformation of public services, but can also support the wider principles of public governance. The chapter explores the characteristics of co-production, its theoretical underpinnings and its different forms: co-commissioning, co-design, co-delivery and co-assessment (the four co's). Bovaird and Loeffler then analyse how the four co's might contribute to the 'principles of good governance'. They suggest that the concern of many authors may be overdone about whether the governance of co-production can meet such high standards as the governance of professionally-provided services. The authors state that co-production may actually play a counterbalancing role to the over-dominance of politicians or state bureaucrats in interactive governance. Finally, Bovaird and Loeffler look at the empirical evidence and suggest some conclusions and implications arising from this analysis.

Voorberg and Bekkers argue in Chapter 13 that Western governments are retreating from the public domain and are actively seeking alternative forms of public service delivery. These forms are increasingly interactive and reliant on the competences and expertise of citizens. Citizens are no longer considered as (just) end-users of public services, but are expected to be co-creators. Using the conceptual framework of Schneider and Ingram (1993), Voorberg and Bekkers explore what such a social construction of citizens implies for citizens who can be considered as co-creators, but also for citizens who initially do not belong to the group of co-creators. They argue that mainstreaming citizens as such might strengthen certain democratic values such as responsiveness and equal consideration, but at the same time, endangers others such as equal access to public service delivery and service diversity. 
Duniam and Eversole explore in Chapter 14 the juxtaposition between community modes of governance and formal institutions of government with reference to recent empirical research in the Australian state of Tasmania. Past research has suggested that community modes of governance are regularly deployed to fill service gaps in rural Australian communities. Local people take informal joint action across organizational boundaries to fill gaps left by more formal government systems. These 'community' modes of governance mobilize local knowledge and relationships in creative ways, yet they are often overlooked when government organizations attempt to engage with rural communities. Their chapter demonstrates how rural people use social enterprises to mobilize local resources for problem-solving - including resources from local government - filling gaps that formal systems miss. Duniam and Eversole argue that social enterprises, as 'hybrid' organizations, represent a strategy for navigating the tensions between community and bureaucratic modes of governance at the local level.

Chapter 15 by Patterson, Ranahan, Silverman and Yin examines community benefits agreements (CBAs), an emerging form of public engagement and governance related to urban revitalization policy in the USA. CBAs are equity-based development strategies that focus on linking community benefits to private and non-profit sector urban revitalization projects. They exemplify emerging approaches to urban revitalization and governance that involve three distinct interests: labour and grassroots organizations; developers from the private and non-profit sectors; and local government. In this new form of governance, the government's traditional role in the implementation of urban revitalization projects has shifted to public and non-profit organizations. This shift reflects a more general trend toward the replacement of direct government implementation with shared governance strategies. In their chapter, Patterson et al. review empirical research on CBAs and then present four critical case studies. Their analysis focuses on public engagement strategies and governance in the CBA process. In particular, Patterson et al. compare negotiated agreements in which private versus non-profit sector developers play a key role.

Brandsen argues in Chapter 16 that in the context of interactive governance, self-organization represents the most extreme manifestation of active involvement. Rather than participating in government initiatives, citizens take the initiative themselves and government may or may not be involved. Brandsen presents key issues in helping to understand this phenomenon. He argues that the dream of self-organizing citizens is part of a longer-term trend, despite its appearance of fashionable frill. The chapter discusses how different theories can help us explain why and how 
citizens organize themselves. Brandsen also discusses dilemmas faced by governments in dealing with self-organization: more so than other types of interactive governance, civic-induced interactive governance raises moral questions over the role of public authorities and the legitimacy of their interventions. The chapter ends with a brief reflection on the future potential for collaboration between government and self-organizing citizens.

Bartels argues in Chapter 17 that interactive governance has rapidly been institutionalized in the public sector, but cannot guarantee productive dynamics and positive outcomes. He argues that making interactive governance work hinges on how it takes shape through encounters in daily practice. In their interactions, stakeholders can enact predetermined institutional interests, procedures and routines (logic of the organization) or engage in a process of discovering how best to address the needs and dynamics at hand (law of the situation). This framework is empirically grounded in and practically illustrated by the case of a Neighbourhood Practice Team in Amsterdam-West, the Netherlands. The analysis critically appraises its successful practice of 'doing what's necessary': following the needs of the residents and the dynamics of the neighbourhood rather than abiding by pre-set interests, goals and procedures. Bartels explains how this works, what challenges it runs into, and why it makes a difference.

Schenk, Czaika, Rumore and Russo start their contribution (Chapter 18) by arguing that interactive governance processes often require the use of contentious and ambiguous scientific and technical information. Parties with divergent knowledge-claims and interests are more likely to reach stable and equitable agreements if they arrive at a shared understanding of the credibility, legitimacy and relevance of that information. Joint Fact Finding (JFF) is an interactive governance approach that brings stakeholders together to collectively define what information is needed for decision-making, how that information ought to be collected, and who ought to collect it. Through doing so, JFF can help involved parties to devise a shared fact pattern and reach agreement about what is known and what remains uncertain. In this chapter Schenk et al. introduce the JFF process and discuss how the approach may be understood via the instrumental, cultural and democratic perspectives on interactive governance. It then provides examples of JFF in the USA to illustrate how the process works and how it can contribute to interactive governance.

Chapter 19 by van Buuren, Duijn, Ellen and Ottow also deals with knowledge co-production in interactive governance settings. The authors focus on the extent to which actors can achieve 'negotiated knowledge', knowledge that is generated, shared and accepted by various actors in the 
interactive governance arena. However, van Buuren et al. claim that knowledge co-production is anything but easy. It is hindered by the presence of deep cleavages between the domain of experts, policy-makers and stakeholders/citizens, who use different ways of knowing and different criteria to assess the relevance of knowledge. In their chapter van Buuren et al. explore and reflect on the limits and limitations of knowledge co-production. They build on three cases from the Dutch water and soil management and climate adaptation policies. A key limitation is that negotiated knowledge from interactive arenas is often not carefully interlinked with formal decision-making procedures, and therefore hampers impact. Van Buuren et al. conclude their chapter by reflecting upon the question of how policy-makers and managers can deal with such limitations of knowledge co-production.

\subsection{Reflections on Management and Political and Boundary- spanning Leadership}

Interactive governance is not self-executive but needs careful attention in preparing, embedding and implementing interactive governance practices. Different forms of management come to the fore, such as community leadership, network management, meta-governance and boundaryspanning leadership. Within this theme several authors discuss leadership strategies to foster and realize democratic anchorage, effectiveness and accountability in interactive governance. New leadership and management issues appear as interactive governance processes and arrangements demand new and different approaches, competences and methods. What are the challenges, opportunities and coping mechanism of new community leaders within citizen self-organization and existing public managers? How do officials and politicians struggle with their role and position towards interactive governance and which new forms of political leadership and engagement can they develop in legitimately and effectively dealing with the emergence of new interactive governance processes? Several chapter contributors pay attention to these issues.

Klijn argues, in Chapter 20, that interactive governance and the plea for participation and self-organization are strongly informed and motivated by ideas about democracy and participation. Analysing these processes tends to emphasize the way citizens participate in the process and the degree of influence they have. In his chapter Klijn argues that the managerial effort of interactive governance is likely to be as important (maybe even more) as the democratic character. He claims that the contrast often made between managerialism and democracy often vastly overemphasizes the conflict between the two and ignores the fact that 
good effective citizen participation with any impact needs strong management of network interactions in which the interactions take place. By using some recent research, Klijn indicates that there is a strong correlation between managerial activity, inclusion of stakeholders and performance. He then critically reflects on accountability issues that managers often face in interactive governance settings. Within this chapter, he goes deeper into these accountability problems and proposes possible solutions for these problems.

In Chapter 21 Sørensen and Torfing deal with the concept of metagovernance. The concept of meta-governance provides, in their view, important insights into how public leaders and managers can govern the various arenas of collaborative governance. They critically reflect on the expanding research on meta-governance and argue that this literature tends to disregard the political aspects of meta-governance and neglects the specific role of politicians in meta-governing interactive governance arenas. In order to remedy this problem, Sørensen and Torfing set out some new ideas about how politicians can exercise vertical political leadership vis-à-vis horizontal networks by deploying some strictly political forms of meta-governance that enhance the democratic legitimacy of interactive governance. Their argument is based on a critical scrutiny of recent theories of meta-governance and political leadership.

In Chapter 22 van Meerkerk and Edelenbos go deeper into the concept of boundary-spanning leadership to reflect on how tensions between civic initiatives and existing political and governmental institutions can be managed. They argue that to make civic-induced interactive governance work, boundary-spanning activities on both sides of the state-society boundary are needed. By using the insights from a longitudinal in-depth case study on community self-organization in the Netherlands, they delve deeper into the boundary-spanning profiles and boundary-spanning practices of the key figures in this case. Their reflective case study seeks to 'put a face' on boundary-spanning leadership and to contextualize it within the research on civic initiatives. They specifically examine how the different boundary spanners, positioned in diverse institutional and organizational settings, contributed to the organizational and democratic anchorage of this community self-organization in which citizens take the initiative in developing and maintaining a specific area.

\section{CONCLUSION}

The book concludes with Chapter 23 in which the editors, Edelenbos and van Meerkerk, discuss the recurring and prominent issues raised by the 
contributors in the previous chapters. In this chapter the contributions are synthesized along the distinction between civic-induced and governmentinduced interactive governance and the three perspectives as introduced in this chapter, leading to an agenda for research and debate on interactive governance. They also introduce the concept of cooperative democracy in order to sketch a new form and approach to civic-induced interactive governance that stresses the emergence of civic initiatives and the challenge for governments to find their (new) positions and roles in making interactive governance meaningful, legitimate and effective.

\section{REFERENCES}

Bang, H.P. (2004), 'Culture governance: governing self-reflexive modernity', Public Administration, 82(1), 157-90.

Bang, H.P. (2009), "Yes we can": identity politics and project politics for a late-modern world', Urban Research and Practice, 2(2), 1-21.

Bang, H.P. and E. Sørensen (1999), 'The everyday maker: a new challenge to democratic governance', Administrative Theory \& Praxis, 21(3), 325-41.

Beck, U., A. Giddens and S. Lash (1994), Reflexive Modernization: Politics, Tradition and Aesthetics in the Modern Social Order, Palo Alto, CA: Stanford University Press.

Betz, H.G. (1993), 'The new politics of resentment', Comparative Politics, 25, 413-27.

Boonstra, B. (2015), Planning Strategies in an Age of Active Citizenship: A Post-structuralist Agenda for Self-organization in Spatial Planning, Doctoral thesis, Groningen: PhD Series InPlanning.

Boonstra, B. and L. Boelens (2011), 'Self-organization in urban development: towards a new perspective on spatial planning', Urban Research \& Practice, 4(2), 99-122.

Dalton, R.J. (2004), Democratic Challenges. Democratic Choices. The Erosion of Political Support in Advanced Industrial Democracies, New York: Oxford University Press.

Dalton, R.J. (2008), 'Citizenship norms and the expansion of political participation', Political Studies, 56(1), 76-98.

Dean, M. (2003), 'Culture governance and individualisation', in H. Bang (ed.), Governance as Social and Political Communication, Manchester: Manchester University Press.

De Moor, T. (2013), 'Homo cooperans: instituties voor collectieve actie en solidaire samenleving', inaugural lecture, Utrecht: Utrecht University.

Dietz, T., E. Ostrom and P.C. Stern (2003), 'The struggle to govern the commons', Science, 302(5652), 1907-12.

Dryzek, J. (2010), Foundations and Frontiers of Deliberative Governance, Oxford: Oxford University Press. 
Edelenbos, J. (2005), 'Institutional implications of interactive governance: insights from Dutch practice', Governance: An International Journal of Policy, Administration and Institutions, 18(1), 111-34.

Edelenbos, J. and E.H. Klijn (2006), 'Managing stakeholder involvement in decision making: a comparative analysis of six interactive processes in the Netherlands', Journal of Public Administration Research and Theory, 16(3), 417-46.

Edelenbos, J. and G.R. Teisman (2011), 'Symposium on water governance. Prologue: Water governance as a government's actions between the reality of fragmentation and the need for integration', International Review of Administrative Sciences, 77(1), 5-30.

Edelenbos, J. and I.F. van Meerkerk (2016), 'Normative theory', in J. Torfing and C. Ansell (eds), Handbook on Theories of Governance, Cheltenham, UK and Northampton, MA, USA: Edward Elgar Publishing, pp. 402-15.

Foucault, M. (1991), 'Governmentality', in G. Burchell, C. Gordon and P. Miller (eds), The Foucault Effect: Studies in Governmentality, Hemel Hempstead: Harvester Wheatsheaf.

Fung, A. and E.O. Wright (2003), Deepening Democracy: Innovations in Empowered Participatory Governance, London: Verso.

Giddens, A. (1984), The Constitution of Society: Outline of a Theory of Structuration, Cambridge: Polity Press.

Hajer, M. and H. Wagenaar (eds) (2003), Deliberative Policy Analysis: Understanding Governance in the Network Society, Cambridge: Cambridge University Press.

Hardin, R. (1999), 'Do we want trust in government?', in M.E. Warren (ed.), Democracy and Trust, Cambridge: Cambridge University Press, pp. 22-41.

Healey, P. (2015), 'Citizen-generated local development initiative: recent English experience', International Journal of Urban Sciences, 19(2), 109-18.

Held, D. (2006), Models of Democracy, Cambridge: Polity Press.

Hirst, P. (2000), 'Democracy and governance', in J. Pierre (ed.), Debating Governance: Authority, Democracy, and Steering, Oxford: Oxford University Press, pp. 13-35.

Hurenkamp, M., E. Tonkens and J.W. Duyvendak (2006), Wat Burgers Bezielt, The Hague: UvA/NICIS Kenniscentrum Grote Steden.

Irvin, R.A. and J. Stansbury (2004), 'Citizen participation in decision making: is it worth the effort?', Public Administration Review, 64(1), 55-65.

Jameson, P.K. and M. Hosack (1995), 'Citizen initiatives in Florida: an analysis of Florida's constitutional initiative process, issues, and alternatives', Florida State University Law Review, 23, 417-61.

Kisby, B. (2010), 'The big society: power to the people?', Political Quarterly, 81(4), 484-91.

Klijn, E.H. and C. Skelcher (2007), 'Democracy and governance networks: compatible or not?', Public Administration, 85(3), 587-608.

Kooiman, J. (ed.) (1993), Modern Governance: New Government-Society Interactions, London: Sage.

Kooiman, J. (2003), Governing as Governance, London: Sage.

Koppenjan, J. and E.H. Klijn (2004), Managing Uncertainties in Networks, London: Routledge. 
Le Galès, P. (2001), 'Urban governance and policy networks: on the urban political boundedness of policy networks. A French case study', Public Administration, 79(1), 167-84.

Leach, W.D. and N.W. Pelkey (2001), 'Making watershed partnerships work: a review of the empirical literature', Journal of Water Resources Planning and Management, 127(6), 378-85.

Lorentzen, H. and L. Hustinx (2007), 'Civic involvement and modernization', Journal of Civil Society, 3(2), 101-18.

Lowndes, V., L. Pratchett and G. Stoker (2001), 'Trends in public participation: part 1 - local government perspectives', Public Administration, 79(1), 205-22.

MacPherson, C.B. (1979), The Life and Times of Liberal Democracy, Oxford: Oxford University Press.

March, J.G. (1994), A Primer on Decision Making, New York: Free Press.

March, J.G. and J.P. Olsen (1995), Democratic Governance, New York: Free Press.

Marien, S., M. Hooghe and E. Quintelier (2010), 'Inequalities in noninstitutionalised forms of political participation: a multi-level analysis of 25 countries', Political Studies, 58(1), 187-213.

Marinetto, M. (2003), 'Who wants to be an active citizen? The politics and practice of community involvement', Sociology, 37(1), 103-20.

Mayer, I., J. Edelenbos and René Monnikhof (2005), 'Interactive policy development: undermining or sustaining democracy?', Public Administration, 83(1), 179-99.

Munro, H. (2008), 'When do community leaders make a difference? Exploring the interactions of actors and institutions', PhD thesis, Institute of Local Government Studies, University of Birmingham.

Oesch, D. (2008), 'Explaining workers' support for right-wing populist parties in Western Europe: evidence from Austria, Belgium, France, Norway, and Switzerland', International Political Science Review, 29(3), 349-73.

Ostrom, E. (1998), 'A behavioral approach to the rational choice theory of collective action: Presidential address, American Political Science Association, 1997', American Political Science Review, 92(1), 1-22.

Papadopoulos, Y. (2003), 'Cooperative forms of governance: problems of democratic accountability in complex environments', European Journal of Political Research, 42(4), 473-501.

Peters, B.G. (2010), 'Bureaucracy and democracy', Public Organization Review, 10, 209-22.

Pierre, J. (2000), Debating Governance: Authority, Steering, and Democracy, Oxford: Oxford University Press.

Pierre, J. and B. Guy Peters (2000), Governance, Politics and the State, Basingstoke: Macmillan.

Putnam, R. (2000), Bowling Alone: the Collapse and Revival of American Community, New York: Simon \& Schuster.

Rhodes, R.A.W. (1997), Understanding Governance. Policy Networks, Governance, Reflexivity, and Accountability, Buckingham: Open University Press.

Roberts, N. (2004), 'Public deliberation in an age of direct citizen participation', The American Review of Public Administration, 34(4), 315-53. 
Rose, N. (1999), Powers of Freedom: Reframing Political Thought, Cambridge: Cambridge University Press.

Schneider, A. and H. Ingram (1993), 'Social construction of target populations: implications for politics and policy', American Political Science Review, 87(2), 334-47.

Sørensen, E. (2002), 'Democratic theory and network governance', Administrative Theory and Praxis, 24(4), 693-720.

Sørensen, E. and J. Torfing (eds) (2007), Theories of Democratic Network Governance, Cheltenham, UK and Northampton, MA, USA: Edward Elgar Publishing.

Sørensen, E. and J. Torfing (2009), 'Making governance networks effective and democratic through metagovernance', Public Administration, 87(2), 234-58.

Stolle, D. and M. Hooghe (2005), 'Inaccurate, exceptional, one-sided or irrelevant? The debate about the alleged decline of social capital and civic engagement in Western societies', British Journal of Political Science, 35(1), 149-67.

Taylor, M. (2007), 'Community participation in the real world: opportunities and pitfalls in new governance spaces', Urban Studies, 44(2), 297-317.

Tolbert, C.J. and K. Mossberger (2006), 'The effects of e-government on trust and confidence in government', Public Administration Review, 66(3), 354-69.

Torfing, J., B.G. Peters, J. Pierre and E. Sørensen (2012), Interactive Governance. Advancing the Paradigm, Oxford: Oxford University Press.

Uitermark, J. (2014), Verlangen naar Wikitopia, Rotterdam: Erasmus Universiteit Rotterdam.

Van Kersbergen, K. and F. Van Waarden (2004), “"Governance” as a bridge between disciplines: cross-disciplinary inspiration regarding shifts in governance and problems of governability, accountability and legitimacy', European Journal of Political Research, 43(2), 143-71.

van Meerkerk, I. (2014), 'Boundary-spanning in governance networks. A study about the role of boundary spanners and their effects on democratic throughput legitimacy and performance of governance networks', Doctoral thesis, Rotterdam: Erasmus University Rotterdam.

van Meerkerk, I., B. Boonstra and J. Edelenbos (2013), 'Self-organization in urban regeneration: a two-case comparative research', European Planning Studies, 21(10), 1630-52.

van Meerkerk, I., J. Edelenbos and E.H. Klijn (2015), 'Connective management and governance network performance: the mediating role of throughput legitimacy. Findings from survey research on complex water projects in the Netherlands', Environment and Planning C: Government and Policy, 33(4), 746-64.

Warren, M.E. (2009), ‘Governance-driven democratization', Critical Policy Studies, 3, 3-13.

Williams, P. (2002), 'The competent boundary spanner', Public Administration, 80, 103-24.

Wyler, S. and P. Blond (2010), 'To buy, to bid, to build: community rights for an asset owning democracy', London: ResPublica and NESTA. 